
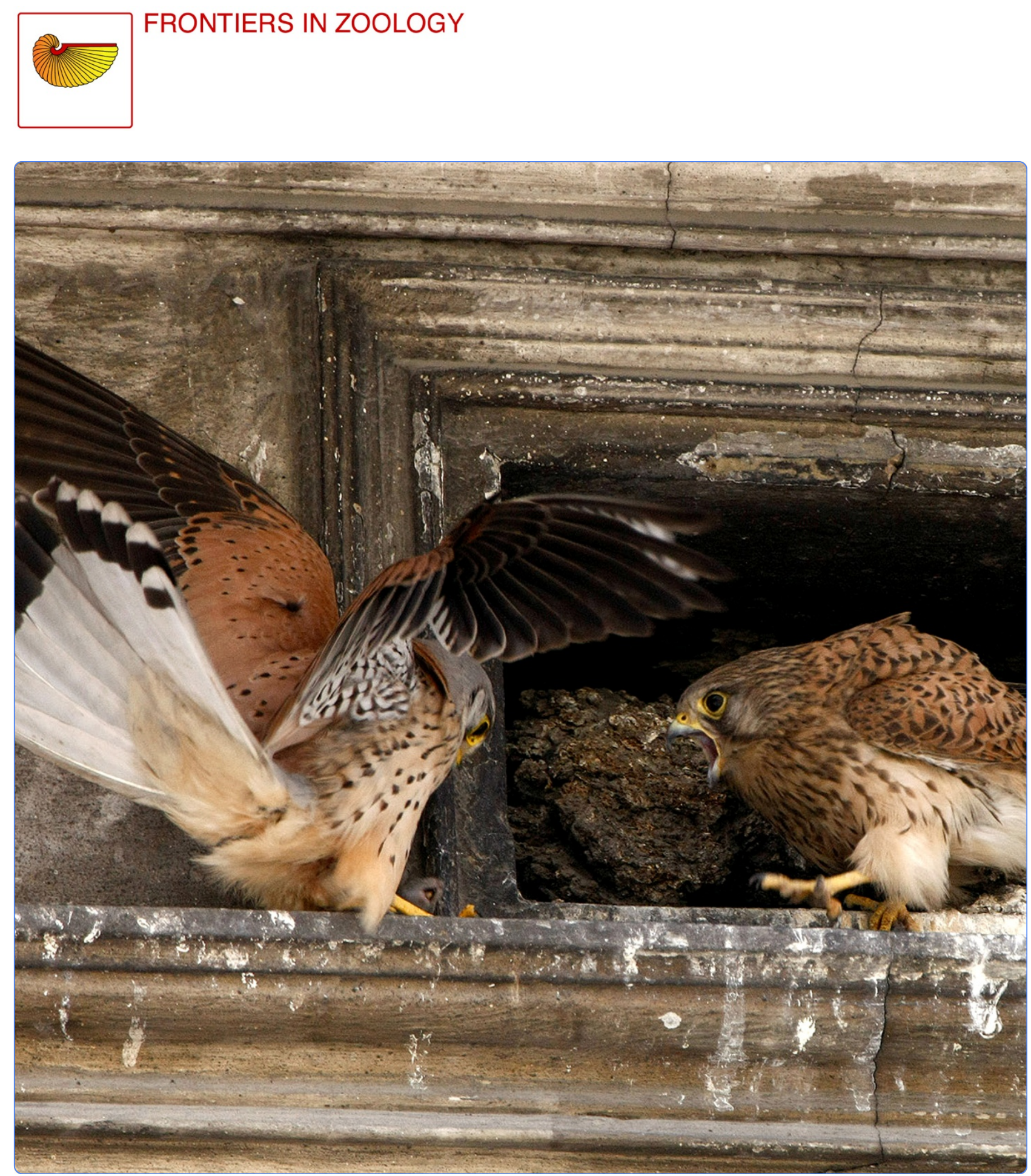

\title{
Hard times in the city - attractive nest sites but insufficient food supply lead to low reproduction rates in a bird of prey
}

Sumasgutner et al. 


\title{
Hard times in the city - attractive nest sites but insufficient food supply lead to low reproduction rates in a bird of prey
}

Petra Sumasgutner ${ }^{1,2^{*}}$, Erwin Nemeth ${ }^{3,4}$, Graham Tebb ${ }^{5}$, Harald W Krenn ${ }^{1}$ and Anita Gamauf ${ }^{1,2}$

\begin{abstract}
Introduction: Urbanization is a global phenomenon that is encroaching on natural habitats and decreasing biodiversity, although it is creating new habitats for some species. The Eurasian kestrel (Falco tinnunculus) is frequently associated with urbanized landscapes but it is unclear what lies behind the high densities of kestrels in the urban environment.

Results: Occupied nest sites in the city of Vienna, Austria were investigated along a gradient of urbanization (percentage of land covered by buildings or used by traffic). Field surveys determined the abundance of potential prey (birds and rodents) and the results were compared to the birds' diets. A number of breeding parameters were recorded over the course of three years. The majority of kestrels breed in semi-natural cavities in historic buildings. Nearest neighbour distances (NND) were smallest and reproductive success lowest in the city centre. Abundance of potential prey was not found to relate to the degree of urbanization but there was a significant shift in the birds' diets from a heavy reliance on rodents in the outskirts of the city to feeding more on small birds in the centre. The use of urban habitats was associated with higher nest failure, partly associated with predation and nest desertion, and with significantly lower hatching rates and smaller fledged broods.
\end{abstract}

Conclusions: High breeding densities in urban habitats do not necessarily correlate with high habitat quality. The high density of kestrel nests in the city centre is probably due to the ready availability of breeding cavities. Highly urbanized areas in Vienna are associated with unexpected costs for the city dwelling-raptor, in terms both of prey availability and of reproductive success. The kestrel appears to be exploiting the urban environment but given the poor reproductive performance of urban kestrels it is likely that the species is falling into an ecological trap.

Keywords: Diet choice, Ecological trap, Falco tinnunculus, Historical building structure, Nest site choice, Nest survival, Prey availability, Urban exploiter, Urban gradient

\section{Introduction}

Rapidly increasing urbanization is a global phenomenon that affects not only humans but also animals and plants [1]. While native biodiversity often declines [2], urbanization promotes the biotic homogenization of species assemblages [3-5]. Because of the loss of natural habitat, urbanization generally leads to a complete restructuring of vegetation and species composition and has thus become a major concern in conservation biology [6,7].

\footnotetext{
* Correspondence: petra.sumasgutner@univie.ac.at

'Department of Integrative Zoology, University of Vienna, Althanstraße 14, Vienna A-1090, Austria

${ }^{2}$ 1st Zoological Department, Museum of Natural History Vienna, Burgring 7, Vienna A-1010, Austria

Full list of author information is available at the end of the article
}

The urban environment can induce dramatic changes in animal behaviour, physiology and life-history [8-11]. Within species, studies on passerines have shown that urban individuals have smaller clutches that are generally laid earlier and that their nestlings are lighter than those of their rural conspecifics [12]. Ultimately, species able to adapt to the challenges posed by increasing urbanization will persist and may even increase, while those that cannot will decline or disappear. Urbanization thus filters bird communities (review in [13]).

The success of urban species appears to be a function of the time since they initially colonized urban areas [14]. The most highly urbanized areas are dominated by 'urban exploiters' ([15,16]), a small number of mainly non-native species, especially nearctic passerines [17], whose success 
in urban areas is largely related to their ability to exploit human resources such as garbage dumps, feeders and nest boxes [18]. Many other species are also found in the centres of large cities, although it is often hard to determine whether they are benefitting or suffering from the urban environment. It is conceivable that the decision to breed in highly urbanized areas might be based on a mistaken assessment of the quality of the environment, with individuals in urban centres suffering from a lower availability of food and lower breeding success. In such cases, the species is said to have fallen into an 'ecological trap' [19].

The Eurasian kestrel (Falco tinnunculus Linnaeus, 1758) is clearly affected by urbanization. It was first recorded breeding in urban environments in the latter half of the 19th century [20] and is now commonly associated with urbanized landscapes [21]. A number of studies have been performed on the diet and breeding success of urban kestrels [22-27] but it is difficult to draw general conclusions from them, as each metropolis provides a unique habitat, differing from others in terms of size [28], building structure [29] and composition of vegetation [30,31]. Despite the previous work, it is still unclear whether the kestrel is a true urban exploiter or whether instead the urban environment represents an ecological trap for the species. The issue can best be addressed by analysing the breeding success of members of an urban population that is sufficiently large to permit the comparison between 'city-dwellers' and birds living in the suburbs.

The urban study area in Vienna $\left(243 \mathrm{~km}^{2}\right)$, Austria has the highest documented density of Eurasian kestrels in a non-colonial urban breeding population ([32,33], c.f. [22-27]) and is ideally suited to a study of this kind. We compared the species' biology along an urban gradient, defined by the density of buildings and areas used by traffic [34]. We considered (1) whether the breeding density of kestrels in urbanized landscapes results mainly from the availability of nest sites, based on the historical building structure and asked (2) whether the use of the urban habitat is associated with differences in annual reproductive rates or (3) a sex bias in nestling survival. We also (4) analysed causes of nest failure and tested whether (5) there is a link between breeding density, reproductive success and availability of prey. Because of the data structure and the relatively small sample size, we pooled the nests investigated more closely into three defined urban zones, using the different zones as discrete explanatory variables (6) to examine the main categories of prey in the kestrels' diet and (7) to relate the diet to the availability of prey.

\section{Results}

\section{Nest site choice and nest site availability}

The kestrel monitoring in 2010 found a total of 251 occupied nests, while in 2011297 nests and in 2012215 nests were found (Figure 1). The figures translate to a breeding density of $89-122$ breeding pairs per $100 \mathrm{~km}^{2}$ in urbanized areas of Vienna. Kestrels predominantly breed in building cavities (69\%, based on nests occupied in 2010), where they largely use roof openings (41\%). Abandoned crow nests in trees are less frequently used (18\% of broods). In rare cases, nest boxes $(6 \% ; 33$ nest boxes were offered in the city) or window boxes (4\%) are used.

The nearest neighbour distance (NND) decreases significantly with an increasing percentage of sealed soil (measured in a circle of radius $\mathrm{r}=500 \mathrm{~m}$ around the nest site, Pearson Correlation, $N_{(2010)}=251, r=0.47, P<0.001$, Figures 1 and 2). An analysis of microhabitat variables showed that the structure of buildings with nest sites differed significantly from those of buildings selected at random (Table 1). Unobstructed roof openings and the availability of green courtyards are more frequent at nest sites than at randomly chosen buildings. Accessible roof openings in buildings chosen at random are only found in the historical city centre with a soil sealing factor of more than $52 \%$.

Unlike their conspecifics in some other European cities (e.g. [22,25,35]), kestrels temporarily leave Vienna during winter and return in spring. The dates when kestrels arrived at their nest sites differed only slightly along the urban gradient (Table $2, P=0.06$ ). In 2010, kestrels arrived at breeding sites in the city centre on average 3 days $( \pm 3.7 S D)$ earlier than at sites in suburban areas and in 2011 the difference was 7 days $( \pm 5.0 S D)$. Males usually occupied nest sites before females but the arrival dates of the two sexes overlapped.

\section{Breeding success and nestling survival along the urban gradient}

There was no obvious effect of the urban gradient on the laying date (Table 2). The ratio of eggs hatched and the sizes of fledged broods depended upon the percentage of sealed soil and the laying date, both of which significantly decreased towards the city centre and for later broods (Table 3). Differences in urbanization and laying date were sufficient to account for $32 \%$ of the variance $\left(R^{2}\right.$ for GLMM) in breeding success (number of fledglings). The clutch size and the fledging rate were significantly influenced by the laying date, with fewer eggs and fewer fledged hatchlings in later nests (Table 3). The mean values and $S D$ for the breeding data are given in Additional file 1.

We found a primary sex ratio of $47 \%$ female and $53 \%$ male offspring (variation from hypothesized 1:1 ratio, $N=$ 71 broods, exact binomial test 2011: $P=0.82$; 2012: $P=$ 0.22 ), whereas the sex ratio at fledging was $54 \%$ female and $46 \%$ male $(N=91$ broods, $0.23<P<0.33)$. Female offspring have a slightly higher rate of survival; of the chicks lost as nestlings ( $N=54$ individuals), 31\% were females and $69 \%$ were males $\left(\chi^{2}=3.84, P=0.05\right)$. 


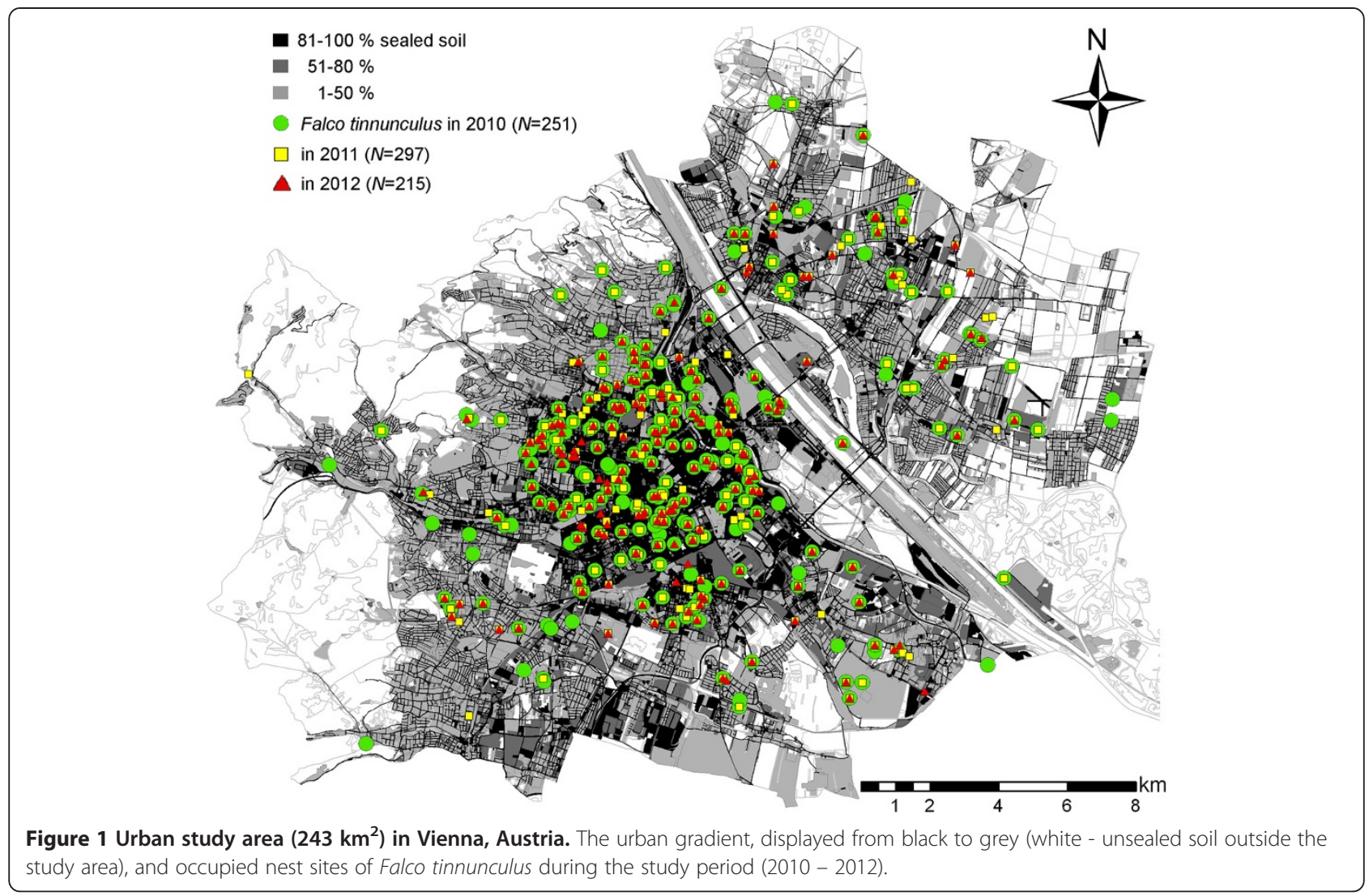

\section{Causes of nest failure}

The initial fixed-effects model of nest survival included laying date and the percentage of sealed soil (Table 4). The best model shows daily survival rates decreasing with percentage of sealed soil from the suburbs towards the city centre and with later laying dates. As there was only a slight difference from the model that includes the age of the nestlings when the nest was found, we are confident

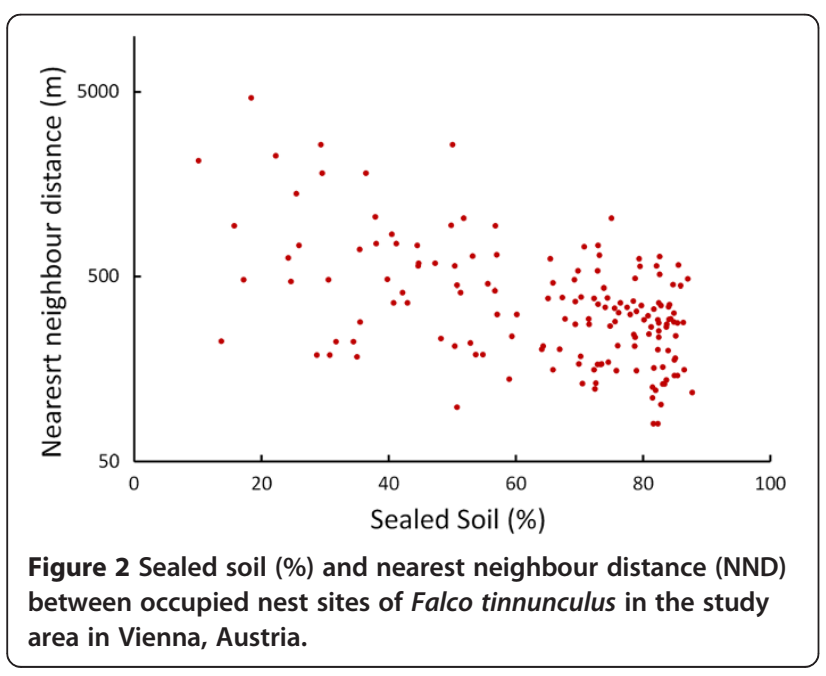

that the results are not biased by when breeding was confirmed (during incubation or during the nestling phase). We tested for the influence of NNDs on nest failure, as reproductive performance is expected to decline with increasing population density, but the resulting model did not meet the criteria for good candidate models. To test tolerance against a potential anthropogenic stressor, we incorporated areas used by traffic in one model but in contrast to the observations on American kestrels (Falco sparverius [36]) we found no correlation.

A total of $33 \%$ of nests failed, with no statistically significant differences between years (Kruskal-Wallis $\chi_{(2,157)}^{2}=$ $2.06, P=0.36$ ). $83 \%$ of nest failures occurred during incubation, with $27 \%$ of failures connected to predation as confirmed by direct observation (Table 5) and 29\% due to nest desertion. Hooded crows (Corvus cornix) and Carrion crows (Corvus corone) are both common in Vienna but we found no significant difference in the abundance of these potential nest predators along the urban gradient $(Z=$ $0.76, P=0.45)$.

\section{Availability of prey}

No significant relationship was found between abundance of prey and breeding success. Neither the number of preysized birds nor the abundance of rodents was able to predict the occurrence of successful breeders (GLM with 
Table 1 Habitat differences between buildings chosen at random $(N=240)$ and nest sites $(N=195)$ on buildings shown with a GLM with binomial error structure (random point $=0$, nest site $=1$ ) and a logit link function

\begin{tabular}{|c|c|c|c|c|c|}
\hline Variable & Estimate & $S E$ & $T$-value & $P$-value & Sign. \\
\hline Intercept & -3.11 & 0.70 & -4.46 & $<0.0001$ & $* * *$ \\
\hline Roof-openings [open $=1$, closed $=0$ ] & 4.12 & 0.50 & 8.29 & $<0.0001$ & *** \\
\hline Façade $[$ smooth $=0$, not smooth $=1]$ & -0.46 & 0.26 & -1.79 & 0.07 & \\
\hline Nest height/Height of the attic [m] & 0.29 & 0.10 & 3.22 & 0.002 & ** \\
\hline Green courtyard [yes $=1$, no $=0$ ] & 0.88 & 0.27 & 3.33 & $<0.001$ & $* * *$ \\
\hline
\end{tabular}

Significance codes: ${ }^{* * * \prime} 0.001,{ }^{\prime * * \prime} 0.01,{ }^{\prime} \cdot<0.1$.

proportion of successful nests per transect as dependent variable with binomial error distribution and logit link function [37] and both average numbers of birds and rodents as two predictors in the model, $N=25$ transects, $P$ for all predictors was not significant; birds: $Z=1.13, P=$ 0.25 ; rodents: $Z=0.42, P=0.42$ ).

The abundance of prey-sized species of bird varies with location along the urban gradient. No difference was found for thrush-sized birds (GLM with urban zone as predictor variable $Z=0.91, P=0.36$ ) but sparrowsized birds were more abundant in suburban areas $(Z=$ 11.08, $P<0.001)$ and pigeons - which our pellet analysis confirmed were included in kestrels' diet - were more abundant in the city centre $(Z=3.49, P<0.001)$.

The rodent survey included 2,676 trapping events $(N=$ 129 individuals) and caught almost exclusively field mice of the genus Apodemus (98.4\% of three species, A. sylvaticus, A. flavicollis and A. uralensis), with very small numbers of house mice Mus musculus, brown rats Rattus norvegicus and bank voles Clethrionomys glareolus recorded. In view of the relatively minor importance of field mice in the diet of urban kestrels (see below) and of the small sample size, an analysis of the trapping data by urban zone was not undertaken. Of the species trapped in the survey, only the bank vole is active by day [38], so the results indicate that diurnal rodents are hardly available in the city. The situation is in stark contrast to the surrounding areas, where diurnal voles (especially Microtus arvalis) are common $[39,40]$.

\section{Diet choice in three urban zones}

Pellet analysis showed no difference in the proportions of the main categories of prey between years (Kruskal-Wallis $X^{2}$-test: $\left.0.22, P<0.62\right)$. There were differences between urban zones: pellets in the city centre $(N=18$ nest sites) consisted of $48.5 \%$ (by biomass, for details of calculation see Methods) mammals, 39\% birds, 3.5\% reptiles and 9\% insects, while pellets found in the mixed zone $(N=10$ nest sites) consisted of $56.6 \%$ mammals, $29.8 \%$ birds, $1.5 \%$ insects and $12.1 \%$ reptiles. The pellets found in suburban areas $(N=9$ nest sites) showed $79.6 \%$ mammals, $12.2 \%$ birds, $4 \%$ insects and $4.2 \%$ reptiles. We could not identify all pellet contents to the species level but $70.4 \%$ of small mammals that could be identified were Microtus arvalis voles (sub-sample size: $N=152$ individuals). Other mammal species identified were $13.0 \%$ field mice (Apodemus spp.) and 8.3\% shrews (Soricidae).

The ratio of pairs that preyed mainly on mammals as opposed to on birds (based on the estimated biomass per nest site) differed significantly between urban zones (mammals: Kruskal-Wallis $\chi_{(2)}^{2}=7.54, P=0.02$ and birds: $\left.\chi_{(2)}^{2}=7.24, P=0.03\right)$, as did Levin's index for breadth of diet, which was highest in the city centre (Kruskal-Wallis $\chi_{(2)}^{2}=8.34, P=0.02$; Levin's index in the city centre: 4.02 ,

Table 2 Dependence of breeding time (2010-2012) on the urban gradient (measured as percentage of sealed soil in $r=500 \mathrm{~m}$ around the nest site) and nearest neighbour distance (NND) as fixed effect in a generalized linear mixed model (GLMM)

\begin{tabular}{|c|c|c|c|c|c|c|}
\hline Breeding time & Estimate & SE & $T$-value & $\operatorname{Pr}(>|t|)$ & expl.dev.(\%) & Sign. \\
\hline \multicolumn{7}{|c|}{ Arrival date $^{\ddagger}(N=333)$} \\
\hline Sealed soil & -12.36 & 6.47 & -1.91 & 0.0568 & 54.74 & \\
\hline $\mathrm{NND}^{+}$ & -2.49 & 2.90 & -0.86 & 0.3920 & 13.85 & NS \\
\hline (Intercept) & 272.53 & 14.33 & 19.01 & $<0.0001$ & & $* * *$ \\
\hline \multicolumn{7}{|c|}{ Laying date ${ }^{\ddagger}(N=157)$} \\
\hline Sealed soil & 7.95 & 6.79 & 1.17 & 0.2440 & 40.68 & NS \\
\hline (Intercept) & 28.53 & 4.86 & 5.85 & $<0.0001$ & & $* * *$ \\
\hline
\end{tabular}

The nest site ID and the study year were included as random factors. The error family was chosen according to the type of response variable as Gaussian family and identity link function. Explanatory deviance (in \%) is given for each fixed effect. Note: ${ }^{\ddagger \prime}$ data presented as residuals with the study year, ${ }^{\prime \prime \prime}$ log transformed.

Significance codes: ${ }^{\prime * * \prime \prime} 0.001,{ }^{\prime} \cdot<0.1,{ }^{\prime} N S^{\prime}$ not significant. 
Table 3 Dependence of breeding parameters $(2010-2012, N=157)$ on the urban gradient (measured as percentage of sealed soil in $\mathbf{r}=\mathbf{5 0 0} \mathbf{m}$ around the nest site) as fixed effect in a generalized linear mixed model (GLMM)

\begin{tabular}{|c|c|c|c|c|c|c|}
\hline Breeding parameter & Estimate & SE & $Z$-value & $\operatorname{Pr}(>|z|)$ & $R^{2}$ for GLMM & Sign. \\
\hline Clutch size $(N=138)$ & & & & & 4.5 & \\
\hline Laying date ${ }^{\ddagger}$ & -0.01 & 0.00 & -2.48 & 0.0132 & & * \\
\hline (Intercept) & 1.54 & 0.04 & 38.80 & $<0.0001$ & & $* * *$ \\
\hline Hatching rate & & & & & 15.44 & \\
\hline Laying date ${ }^{\ddagger}$ & -0.04 & 0.01 & -2.94 & 0.0033 & & ** \\
\hline Sealed soil & -2.40 & 1.07 & -2.23 & 0.0255 & & * \\
\hline (Intercept) & 2.54 & 0.78 & 3.24 & 0.0012 & & ** \\
\hline Fledging rate & & & & & 16.04 & \\
\hline Laying date ${ }^{\ddagger}$ & -0.04 & 0.02 & -2.06 & 0.0399 & & * \\
\hline Sealed soil & -2.13 & 1.25 & -1.71 & 0.0882 & & • \\
\hline (Intercept) & 2.60 & 0.99 & 2.62 & 0.0087 & & ** \\
\hline Fledged brood size & & & & & 32.31 & \\
\hline Laying date $^{\ddagger}$ & -0.02 & 0.00 & -4.54 & $<0.0001$ & & $* * *$ \\
\hline Sealed soil & -0.85 & 0.34 & -2.48 & 0.0131 & & * \\
\hline (Intercept) & 1.26 & 0.25 & 5.04 & $<0.0001$ & & $* * *$ \\
\hline
\end{tabular}

The nest site ID and the study year were included as random factors. The error family was chosen according to the type of response variable.

Note: ${ }^{\prime \prime \prime}$ data presented as residuals with the study year.

Significance codes: ${ }^{\prime * * \prime} 0.001,{ }^{\prime * * \prime} 0.01,{ }^{\prime * \prime} 0.05,{ }^{\prime} \bullet^{\prime}<0.1$

mixed zone: 3.10 and suburban area: 1.44). Reptiles were preyed upon more often in the mixed zone (KruskalWallis $X_{(2)}^{2}=5.67, P=0.06$ ), while insects were taken at approximately equal amounts in all urban zones (KruskalWallis $\left.\chi_{(2)}^{2}=0.61, P=0.74\right)$.

\section{Discussion}

\section{Choice and availability of nest site}

Nearest neighbour distances (NND) decreased with increasing percentage of sealed soil (Figure 2) but pairs in the city centre had lower reproductive success, measured in terms of hatching rates and sizes of fledged broods, than pairs in suburban areas. As falcons do not construct nests themselves, their breeding locations are limited by the availability of potential nest sites [41,42]. The correlation between the number of nest sites and the number of roof openings (Table 1) supports the notion that more kestrels breed in the city centre due to the greater availability of building cavities. This can be attributed to the structural element of roof

Table 4 Summary of model-selection according to Mark [106] for fixed-effects models of daily survival rate for kestrel nests $(N=157)$

\begin{tabular}{|c|c|c|c|c|}
\hline Model & $K$ & $\mathrm{AIC}_{\mathrm{c}}$ & $\Delta \mathrm{AIC}_{\mathrm{c}}$ & $\omega_{i}$ \\
\hline 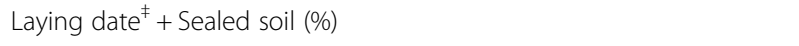 & 3 & 271.42 & 0.00 & 0.5659 \\
\hline Laying date d $^{\neq}$Sealed soil $(\%)+$ Age found & 4 & 272.19 & 0.77 & 0.3852 \\
\hline Laying date d $^{\ddagger}$ & 2 & 276.61 & 5.19 & 0.0422 \\
\hline Distance $(m)^{\dagger}$ from closest open green space $(\geq 1$ ha) + Sealed soil (\%) & 3 & 282.05 & 10.62 & 0.0028 \\
\hline Presence/absence of green courtyard + Sealed soil (\%) & 3 & 282.88 & 11.45 & 0.0018 \\
\hline Sealed soil (\%) & 2 & 283.86 & 12.44 & 0.0011 \\
\hline Age found + Sealed soil (\%) & 3 & 284.89 & 13.47 & 0.0007 \\
\hline Nearest neighbour distance $(\mathrm{m})^{\dagger}$ & 2 & 288.30 & 16.88 & 0.0001 \\
\hline Age found & 2 & 290.46 & 19.04 & 0 \\
\hline Intercept-only model (constant daily survival rate) & 1 & 290.49 & 19.07 & 0 \\
\hline Time Trend & 2 & 290.89 & 19.47 & 0 \\
\hline Traffic area $\left(\mathrm{m}^{2}\right.$, in $r=100 \mathrm{~m}$ around the nest site) ${ }^{\dagger}$ & 2 & 291.27 & 19.85 & 0 \\
\hline
\end{tabular}

$K$ is the number of parameters in the model and $\omega_{i}$ the model weight. Note: ${ }^{\prime \prime}$ ' data presented as residuals with the study year, ${ }^{\prime \prime}$ log transformed. 
openings, which are limited to historical buildings in the city center.

Many species rely on environmental cues for a rapid assessment of habitat quality, thereby reducing the time and cost of finding a suitable breeding site $[43,44,45]$. In environments that have been altered, the use of cues that were formerly reliable might lead to reduced reproduction, turning these environments into ecological traps [19]. Most ecological traps have an anthropogenic origin [46] and migratory species might be more likely to fall into ecological traps created by urban landscapes [47]; compared to residents, migratory birds have more stringent time constraints in assessing the quality of breeding sites $[44,48,49]$. Early arriving individuals usually have preferential access to the best sites and partners, while later arrivals must settle in territories of progressively lower quality $([50,51])$. For territorial birds such as the kestrel this should result in a sort of ideal-despotic distribution [52] where males first occupy the best sites, with poorer sites occupied successively later. We would expect the territories occupied first to show the highest breeding success but our study revealed the opposite to be the case. Kestrels breeding in the centre of Vienna tended to arrive before their suburban conspecifics (Table 2), suggesting that inner-city sites are assessed as being of at least equal quality. However, there were no differences in laying dates along the urban gradient and breeding performance (Table 3) was worse in inner-city districts than in the outskirts. Thus, the first returning kestrels do not select the best breeding sites. Breeding in highly urbanized areas was associated with higher rates of nest failure. Our models of nest survival showed that the percentage of sealed soil and the laying date are the main variables connected to nest failure (Table 4). A close proximity to large open green spaces ( $\geq 1 \mathrm{ha})$ and the presence of green courtyards also increased nest survival.

If highly urbanized areas are not associated with a breeding advantage, why are they occupied ahead of more productive sites at the edge of the city? It is possible that there are simply too few breeding cavities in the outskirts of the city. We found nest site cavities exclusively in the centre and conclude that closed breeding cavities are chosen because of their attractiveness and not because of the limited numbers of other potential types of nest, such as crow nests and window boxes. Attributes of breeding cavities such as limited accessibility to predators, protection from rain and sun and a low probability of collapse have been associated with higher breeding success $[53,54]$. Our study appears to show the opposite, with the selection of breeding cavities in the city centre associated with a lower breeding success.

Nest failure, breeding success and sex-biased nestling survival Most nest failures occurred during incubation of the eggs and were connected to nest desertion or predation
(Table 5). Our results do not indicate a lower rate of nest predation for urban-breeding birds, as has been documented in other studies $([55,56]$ but see [57] reporting higher nest predation by corvids in urban areas). Abandonment occurred during the egg stage (once after hatching) and might have related to territorial disputes or to higher ectoparasite burdens in breeding cavities.

In common with many other raptors, the kestrel shows a size dimorphism, with females larger than males [58]. When individuals of one sex are more costly than the other to produce, sex ratios may differ from 1:1 [59]. A higher mortality of the more expensive sex results in an excess of the cheaper sex at fledging and several species of raptor are known to manipulate the sex ratio of their offspring in response to a range of factors (e.g. [60-62]), including variation in the availability of resources [63,64]. Kestrels have been reported to switch the sex-bias from male-dominated in early nests to female-dominated in later nests [65]. We found that the smaller males and the last chicks to hatch were most likely to die as nestlings. The results are consistent with the finding that kestrels breeding in the centre of Warsaw had more female offspring [66]. The mortality of nestling Montagu's harriers (Circus pygargus) has also been shown to be biased, with smaller males most likely to die, especially if they hatch later in the season [67]. Our results do not necessarily imply a manipulation of the sex ratio but could relate simply to a greater susceptibility of the smaller (male) chicks when food resources are scarce.

\section{Prey availability and diet choice}

Rodents provide a higher nutritional value than avian prey $[68,69]$. Our survey of small mammals suggests that rodents are abundant in the city centre and the outskirts of Vienna but most species are nocturnal and thus hardly accessible to a diurnal raptor. Unlike the lesser kestrel F. naumanni, which is known to hunt during the night under artificial lighting [70], the kestrel is a largely diurnal hunter. Urban kestrels thus have to fly longer distances of at least several kilometres to hunt for their preferred prey $[71,72]$. In the centre of larger cities it may be energetically preferable to switch to less profitable but more common avian prey [73]. Indeed, recent studies indicate that kestrel populations in some larger European cities are increasingly feeding on birds [23,34,74], whereas kestrels in smaller or medium-sized European cities rely largely on a diet of voles (Microtus sp.), as do their rural conspecifics $[24,25,72]$. In general, kestrels are believed to feed on what is locally abundant, although there have been reports of consistent differences in diet composition between neighbouring breeding pairs, presumably reflecting individual preferences for prey or differing abilities at catching different prey types [75]. 
Table 5 Number of nest attempts, reproductive outcome and cause of complete nest failure for Falco tinnunculus in Vienna, Austria 2010-2012

\begin{tabular}{|c|c|c|c|c|c|c|c|c|}
\hline \multirow[b]{2}{*}{ Year } & \multirow[b]{2}{*}{ Nest attempts } & \multicolumn{2}{|c|}{ Reproductive outcome } & \multicolumn{2}{|c|}{ Time of nest failure } & \multicolumn{3}{|c|}{ Cause of nest failure } \\
\hline & & Success (\%) & Failure (\%) & Egg stage & Nestling stage & Abandoned & Predation"\# & Other \\
\hline 2010 & 36 & $21(58 \%)$ & $15(42 \%)$ & 11 & 4 & 5 & 4 & 6 \\
\hline 2011 & 52 & $36(69 \%)$ & $16(31 \%)$ & 14 & 2 & 4 & 6 & 6 \\
\hline 2012 & 69 & $48(70 \%)$ & $21(30 \%)$ & 18 & 3 & 6 & 4 & 11 \\
\hline Total & 157 & $105(67 \%)$ & $52(33 \%)$ & 43 & 9 & 15 & 14 & 23 \\
\hline
\end{tabular}

Note: ${ }^{\text {\#' }}$ based on confirmed predation. If the predation event was not directly observed and the predator not identified, nest failure is assigned to other.

The increased proportion of non-rodent prey in kestrel pellets from the centre of Vienna compared with those from nearer the edge of the city is evidence that the birds generally hunt in the surroundings of their nest sites. Consistent with this idea, nest sites are often located close to green courtyards. A comparative study on generalist and specialist avian predators under fluctuating food conditions has shown that a vole specialist (pallid harrier Circus macrourus) forages less efficiently in poor vole years because the species is less efficient at capturing alternative prey, such as birds [76]. The increased effort required to hunt non-rodent prey may affect the breeding success of kestrels in the centre of Vienna. Our data indicate a trade-off between the ready availability of breeding cavities and the greater distances to hunting grounds, which result in a shift in the main prey taken and a lower breeding success.

\section{Are inner-city buildings ecological traps for an urban raptor?}

The kestrel is not truly an urban species. Although it has a strong preference for breeding in cavities, it does not profit from other human resources, nor does it show a higher degree of sociality and sedentariness [77]. It clearly exploits the urban environment but high breeding densities in human-dominated landscapes do not necessarily indicate that the species benefits in terms of breeding success. Our findings are consistent with a trade-off between the availability of building cavities, which offer nest sites that are protected from potential predators, and the poorer food supply in the city centre. The consequence is that kestrels appear to select nest sites that are associated with increased reproductive failure and smaller fledged broods.

It may be difficult for kestrels to evaluate food availability when they are prospecting for nest sites ([78,79] and citations therein) and errors could cause birds to overestimate the quality of the habitat $[78,80]$ and settle in poor habitats despite the availability of better options. The preference for poorer habitats is a maladaptive behaviour associated with so-called ecological traps (reviewed in $[19,43,46,47,81]$ ). The idea that kestrels are falling into an ecological trap should be further investigated as it could be of conservation concern and might have important consequences for the viability of certain populations.

\section{Conclusions}

In the centre of Vienna, Austria, kestrels frequently breed in roof openings in historical buildings, a structural feature that is not available in the outskirts of the city. A comparison along the urban gradient shows the smallest nearest neighbour distances for pairs that breed in the city centre. The kestrel's favoured prey is rodents but in the centre rodents are less abundant and largely nocturnal and thus not available to diurnally hunting raptors. Kestrels breeding in the centre of Vienna consume more birds, including pigeons, and fewer rodents than kestrels in the outskirts. The city-dwelling raptor pays a high price for life in the city, with a lower reproductive success than birds breeding in the outskirts. The kestrel might appear to be an urban exploiter but given the poor reproductive performance of urban kestrels it is likely that the species is falling into an ecological trap. Although the kestrel is not itself of conservation concern, our findings suggest that other citydwelling species may be faring less well than their abundance in the urban environment would appear to indicate.

\section{Methods}

\section{Study system}

The Eurasian kestrel, hereafter simply referred to as the kestrel, is the most abundant raptor in Vienna, Austria $\left(48^{\circ} 12^{\prime} \mathrm{N}, 16^{\circ} 22^{\prime} \mathrm{E} ; 415 \mathrm{~km}^{2}\right.$, ca. $150-500 \mathrm{~m}$ a. s. $1 ., 1.8$ million inhabitants). The estimated population density of 60-96 breeding pairs per $100 \mathrm{~km}^{2}$ [32] is high compared to that in other European metropolises (e.g. [82,83]) and in rural eastern Austria [84]. Kestrels return to Vienna at the end of March, before pair formation, and remain at their breeding sites until late summer (pers. obs. PS and AG). The study period covered three breeding seasons from March 2010 to August 2012.

The river Danube, lined with riparian forest, divides Vienna in two, making distance from the city centre misleading in terms of defining an urban gradient. We thus define urbanization by the percentage of sealed soil 
(calculated in ArcGIS 10 by ESRI $\odot$, based on land covered by buildings or areas used by traffic on a land allocation map, digitized in 55 categories of land utilization between 2007 and 2010, in a circle of radius $500 \mathrm{~m}$ around the nest sites; sensu [85]). Areas with $<1 \%$ of unsealed soil were defined as rural and excluded from the analysis. Excluding these surroundings, mostly forested and agricultural areas, the urban study area covered $243 \mathrm{~km}^{2}$ (Figure 1). Nests were distributed between percentages of sealed soil of $18 \%$ (most suburban) and $89 \%$ (most urban). By extending our search up to $1 \%$ soil sealing we made sure that NNDs were accurate.

With the help of local media we called on the public to report kestrel nests in Vienna in 2010 and 2011. Additionally, 25 volunteer ornithologists and PS and AG systematically searched the city for nests. Historic nest sites recorded in the BirdLife Austria archive $(N=103)$, occupied nests found during systematic searches $(N=$ 124), locations of kestrel foundlings in the database of the animal shelter and the bird clinic at the University of Veterinary Medicine, Vienna $(N=78)$ and nest sites reported by the general public were confirmed through personal observations during pair formation and courtship and classified as occupied if adults were present on two consecutive visits. During the study period we built a data base of 451 recent nest sites, between $50 \%$ and $65 \%$ of which were occupied each year.

\section{Nest site and habitat parameters}

Two different spatial levels were used to define nest site and habitat parameters. The percentage of sealed soil was calculated in a circle of $\mathrm{r}=500 \mathrm{~m}$ around the nest site (78.5 ha) and expressed as the percentage of land covered by buildings or areas used by traffic. The resulting value is termed the urban gradient. The distance (in m) from the nest site to the nearest open green space was recorded. The size of the nearest open green space, which was either a green courtyard or a park area in the city centre or a lawn (usually in a garden), a meadow or agricultural land in the suburbs, was assigned to one of four categories, $\geq 1$ ha, $\geq 0.5 \mathrm{ha}, \geq 0.25$ ha and $\geq 100 \mathrm{~m}^{2}$.

We also described the building on which the nest was located, recording the nest height $(\mathrm{m})$, façade structure, presence of roof openings or other cavities and presence of green courtyards (between 0.01 and 0.1 ha). We counted the stick nests of crows on the façade and in surrounding trees, as well as the number of window boxes on balconies. The same parameters were measured for 240 buildings chosen at random by placing a $500 \times 500 \mathrm{~m}$ grid over the study area and using each intersection that touched a building. We used the height of the attic as hypothetical 'nest height' variable (as 62\% of actual nest sites were located at attic level).
Habitat data were obtained via a land allocation map $(1: 7,500$, resolution $15 \mathrm{~cm})$, digitized based on georeferenced aerial images provided by the Environmental Protection Bureau of Vienna (MA22-709/2010). Data on building structure were acquired on site.

\section{Breeding parameters}

Occupied nests that were accessible via the attic or by climbing were monitored 4-6 times during each breeding season to determine (1) the laying date, (2) the clutch size, (3) the number of hatched offspring and (4) the number of fledged young. In total, 157 broods were examined (36 nest sites in 2010, 52 in 2011 and 69 in 2012). Kestrels start incubation after the second egg is laid and the date (variable 'laying date') was estimated either directly or by subtracting 30 days from the estimated date of hatching [58]. We defined 1 April as day 1 of the breeding season and numbered all dates of nest inspection thereafter for analysing survival (in total 118 days, see [86] for methodological details). We used the residuals of laying date and study year (calculated in an ANOVA with study year as predictor and laying date as predicted variable) to compare differences along the urban gradient. Additional covariates for nest survival models were percentage of sealed soil (\%), age at which the nest was found, distance (m) from the closest open green space ( $a r e a \geq 1$ ha) as a potential large hunting ground, presence/absence of a green courtyard (between 0.01 and 0.1 ha) with in $r=100 \mathrm{~m}$ from the nest site (factor variable $1 / 0$ ) as a potential small hunting ground, area used by traffic $\left(\mathrm{m}^{2}\right.$, in a circle of $\mathrm{r}=$ $100 \mathrm{~m}$ around the nest site) as an indicator of noise disturbance and the NND (m) to the next active kestrel nest. In two years we additionally recorded for a larger data set $(N=200$ nests in 2010 and $N=185$ nests in 2011) the dates kestrels arrive at their nest sites: the information was provided by ornithologists involved in the breeding bird survey and observers living in direct view of a nest site. Involving the general public allowed us to have observers at accessible nest sites (mostly across the street or 'owners' of occupied window and nest boxes), who provided immediate information on hatching. In other cases we estimated the date of hatching from clutch initiation or egg floating. We marked chicks after hatching with non-toxic ink until they were ringed.

During repeated monitoring, the nestlings were measured, weighed and ringed (with rings from the Ringing Centre Radolfzell, Germany) when they were at least 10 days old (wing length $\geq 54 \mathrm{~mm}$ ). The lengths of the culmen, tail, wing, tarsus, claws and feet [87] were measured for age determination [21]. We determined clutch size, hatching and fledging rates and size of the fledged brood (breeding success) for each nest. The hatching rate was recorded on a continuous scale from 0 (no eggs hatched) to 1 (all eggs hatched). The fledging rate was 
defined similarly and varied from 0 (no hatchling survived) to 1 (all hatched young successfully fledged). The final inspection took place in the last week of the nestling period (24-30 days after hatching). Nestlings fledge after 28-31 days [58], so we considered pairs successful if they produced at least one 28-day-old chick. The size of the fledged brood was therefore the number of nestlings in successful nests at week 4 .

Nests were defined as having failed if there was clutch loss during incubation or if all chicks died after hatching (as a result of predation, starvation, parasite infestation or parental abandonment). We attributed the cause of failure to abandonment if the nest contained intact and cold eggs and no adults were present during two subsequent inspections over 1-2 weeks (sensu [36]) and to predation if predation was observed (crows robbing the nest during the day or broken eggs and marten tracks found in the breeding niche).

\section{Sexing chicks}

Sexing of chicks was based on the CHD system, Intron A [88]. We used the blastoderm or embryonic tissue from unhatched eggs, buccal swabs [89] for small nestlings (210 days) and blood of pinned growing feathers for older nestlings ( $>10$ days). DNA was extracted with the QIAGEN DNeasy Blood \& Tissue Kit following the standard protocol with Proteinase K. Sex was determined based on the 2718R and $2550 \mathrm{~F}$ primer set [90] and confirmed with the Falco-specific $f p 102$ and $f p 49$ primers [91]. PCR amplification was performed in $25 \mu \mathrm{l}$ containing $0.5 \mu \mathrm{l} 10 \mathrm{mM}$ $\mathrm{dNTP}, 0.25 \mu \mathrm{l}$ of each forward and reverse primer (50 $\mathrm{pmol} / \mu \mathrm{l}), 0.25 \mu \mathrm{l}$ Dynazyme Polymerase and $2.5 \mu \mathrm{l} 10 \mathrm{x}$ reaction buffer. PCR was performed with 40 cycles of 2 min at $94^{\circ} \mathrm{C}, 20 \mathrm{~s}$ at $50^{\circ} \mathrm{C}$ and $40 \mathrm{~s}$ at $72^{\circ} \mathrm{C}$ followed by $5 \mathrm{~min}$ at $72^{\circ} \mathrm{C}$. PCR products were visualized on $2 \%$ agarose gels. The primary sex ratio was defined as the sex ratio in the full clutch (recorded in 2011 and 2012). The secondary sex ratio was defined as the sex ratio at fledging (recorded in all years).

\section{Pellet analysis and abundance of prey}

In 2010 and 2011, 637 pellets and remains of prey were collected from 37 different nest sites. We grouped the findings at nest sites according to their location along the urban gradient (sensu [34]), distinguishing between city centre ( 288 pellets, $N=18$ nests with $81-89 \%$ sealed soil), mixed zone (206 pellets, $N=10$ nests, $51-80 \%$ sealed soil) and suburban areas (143 pellets, $N=9$ nests, $18-50 \%$ sealed soil). The pellets were dissected and prey remains classified as 'mammals', 'birds', 'reptiles' or 'insects'. We identified prey to species level where possible with the aid of reference collections at the Museum of Natural History, Vienna. We assessed the minimum number of each category of prey per pellet (largest number of different jaws, upper or lower mandibles, skulls or pairs of incisors in small mammals; plugged feathers in birds; pairs of mandibles, tarsi or ovipositors in insects) and present data as their estimated biomass [g]: $18.8 \mathrm{~g}$ for small mammals, 22.4 $\mathrm{g}$ for sparrow-sized birds, 76.4 $\mathrm{g}$ for thrush-sized birds, $330 \mathrm{~g}$ for pigeons, $10 \mathrm{~g}$ for reptiles, $1.5 \mathrm{~g}$ for Orthoptera and $0.2 \mathrm{~g}$ for Coleoptera $[92,93]$. Diet breadth (B) was calculated according to Levin's index [94] as $B=1 / \Sigma p_{i}^{2}$, where $p_{i}$ is the proportion of the diet represented by prey type i. As variables were not normally distributed, nonparametric tests were used for analysis.

To assess the availability of potential avian prey in 2010 , a team of 25 ornithologists monitored 25 transects $(N=9$ in the city centre, $N=9$ in the mixed zone and $N=7$ in suburban areas) in the course of the Austrian breeding bird survey using the standard method of 5-minute pointcounts in the early morning under stable weather conditions [95]. The ornithologists were recruited by Birdlife Austria and by PS. Each bird recorded within $50 \mathrm{~m}$ of the point was identified based on voice and/or appearance. Analysis was based on prey known from pellet analysis [33] to be taken by kestrels. Potential prey was grouped by size (sparrow-, thrush- and pigeon-sized). Transects were selected by PS in ArcGIS 10 based on the land allocation map and included buildings, areas used by traffic, green courtyards (between 0.01 and 0.1 ha) and parks (between 0.3 and $600 \mathrm{ha}$ ) in the city centre and the mixed zone, and gardens and forest edges in the suburban area. Transects were chosen independently of the location of kestrel nests. They were sampled twice per year, at the beginning of the breeding season (in spring, calendar week 17-18, in April) and during the nestling period (in summer, calendar week $22-23$, in June). Each transect consisted of $12-20$ points at 300-500 m intervals.

The kestrel nest sites were assigned to the closest transects (max. distance $1 \mathrm{~km}, N=2-24$ nests/transect). It is logical to allocate a nest to a transect rather than to a point as two or more count points could be within the hunting grounds of a single pair of kestrels. Furthermore, the assignment takes into account the spatial autocorrelation of neighbouring counting points on a transect. The proportion of successful breeding attempts was calculated for each transect and the figures were used to relate breeding success to availability of prey.

Densities of rodents were estimated by means of the 'minimum number alive method' of [96]. We used 97 Rödl-type live traps [97] in 59 transects, with 10-20 traps in each of 23 different city parks (between 0.3 and 600 ha) across the urban gradient. The traps were checked twice per day (morning and evening) on two consecutive days per area at the start and the end of the 2010 breeding season, resulting in 2,676 trapping events (see [98] for details). 


\section{Statistical analysis}

Differences in habitat between nest sites and buildings chosen at random were evaluated with a generalized linear model (GLM) with binomial error structure and a logit link function. The variables were nest height, facade structure, presence of roof openings or other cavities, and presence of green courtyards. One variable, houses with alcoves, was excluded because there were more roof openings in houses with alcoves $\left(\chi^{2}\right.$-test, $N=248, d f=1$, $P<0.001$ ) and the variable 'roof openings' was obviously related to nest site and thus of higher biological significance.

To analyse the relationship between abundance of prey and breeding success, a GLM was constructed with proportion of successful nests as dependent variable and the two predictors 'avian prey counted' and 'rodents trapped'. To calculate the proportion of successful nests we used the number of successful and failed nests per transect together as response variable fitted to a binomial error distribution. This can be treated as a weighted regression using the individual sample sizes as weights and the logit link function to ensure linearity (see [37] for details).

All distance and area variables were logarithmically transformed. Analysis of the variation of breeding parameters with the urban gradient was performed by generalized linear mixed models (GLMM) with the lmer and glmer functions of the R package 'Ime4' [99], including the nest site ID and the study year as random factors. Error distribution was chosen according to the response variable: Gaussian distribution and the identity link function for clutch date and date of arrival at the nest site; binomial distribution and the logit link function for rates of hatching and fledging (values between 0 and 1); and Poisson distribution with the log link function for the sizes of the clutch and the fledged brood.

Models including soil sealing (urban gradient), NND (nearest neighbour distance) and laying date (timing of breeding) as explanatory variables were evaluated, as was a model including interactions between these variables. All explanatory variables were fitted to a maximal model and removed one by one, with the associated changes in the model deviance assessed by a likelihood ratio test [100]. After each step we calculated the $\mathrm{AIC}_{\mathrm{c}}$ (Akaike Information Criterion, corrected for small sample sizes) and defined the model with the lowest value as the final one [101]. Model selection and model weight is presented in Additional file 2. The proportion of deviance explained (\%) for each fixed effect of the lmer models was analysed with the 'LMER Convenience Functions' package [102]. As this function has not yet been implemented for glmer models (lme4 requires binomial and Poisson error distributions) we assessed estimates of variance explained using $R^{2}$ values, following the method recently described by [103], implemented in the
'MuMIn' package [104]. Details on nest site and habitat parameters used for statistical analysis can be found in Additional file 3. To analyse nest survival we used the 'nest' model in 'RMark' [105,106]. We considered models with $\triangle \mathrm{AIC}<2.0$ to represent good candidates [107]. All statistical analysis was performed with the software $R$ version 3.0.1 (R Development Core Team 2013).

\section{Ethical notes}

The study was performed under license from the Ethics Committee of the University of Veterinary Medicine, Vienna and the Environmental Protection Bureau of Vienna (MA 22/1263/2010/3). All sampling was conducted in strict accordance with current Austrian and EU law and followed the Weatherall Report and the guidelines for the treatment of animals in behavioural research and teaching [108].

\section{Availability of supporting data}

Morphological data on kestrels have been provided to the Ringing Centre in Radolfzell, Germany. Data from the breeding bird survey have been made available to Birdlife Austria and the Environmental Protection Bureau of Vienna (MA22) for use in conservation measures. All supporting data are available from the authors on request.

\section{Additional files}

\section{Additional file 1: Breeding parameters of Falco tinnunculus in Vienna, Austria, 2010-2012 ( $N=157$ nest sites in total) in three urban zones. Results are shown as mean value $\pm S D$. We pooled those nest sites according to their location along the urban gradient (city centre with $81 \%-89 \%$ soil sealing, mixed zone with $51-80 \%$ soil sealing, and suburban area with $18-50 \%$ soil sealing). \\ Additional file 2: Model selection for Table 3 in results section (dependence of breeding parameters on urbanization). Models are ranked according to the Akaike Information Criterion, corrected for small sample sizes $\left(A I C_{C}\right)$. The $\triangle A I C_{C}$ indicates $A_{C} C_{C}$ differences between a particular model and the best-fitting model with the smallest $A I C_{c}$. Akaike weights $\left(\omega_{i}\right)$ indicate the contribution of each model to the average of all candidate models and $K$ the number of parameters. Variables included in and excluded from a particular model are indicated by $1 \mathrm{~s}$ and $0 \mathrm{~s}$, respectively. Id - laying date, ss - sealed soil, NND - nearest neighbour distance. Good candidate models are printed in bold.}

Additional file 3: Nest site and habitat parameters used for statistical analysis.

\section{Abbreviations}

$\mathrm{AIC}_{\mathrm{c}}$ : Akaike information criterion, corrected for small sample sizes; GLM: Generalized linear model; GLMM: Generalized linear mixed; NND: Nearest neighbour distance.

\section{Competing interests}

The authors declare that they have no competing interests.

\section{Authors' contributions}

The original idea and study design came from PS, AG and HWK. PS performed the field and laboratory work; help by others is accordingly acknowledged. PS, EN and GT analysed the data. The manuscript was prepared by PS, EN, GT and AG and approved by all authors. 


\section{Acknowledgements}

This study was supported by the Environmental Protection Bureau of Vienna (MA 22-2220/2010) and the Vienna Science and Technology Fund (H-2249/ 2010). PS was supported by the University of Vienna ('Doctoral Research Fellowship' http://www.univie.ac.at) and the Austrian Academy of Sciences ('DOC-fFORTE scholarship' http://www.oeaw.ac.at). We are grateful to Judith Düesberg, Simon Engelberger, Tomislav Gaspar, Julia Gstir, Nele Herdina and Katharina Spreitzer for the pellet analysis and to Gerda Mitter for providing data from the small mammal survey. Genetic analysis was conducted at the Laboratory of Molecular Systematics in the Museum of Natural History Vienna. We especially thank Elisabeth Haring, Luise Kruckenhauser and Barbara Däubl for their support. We are indebted to the Vienna firefighters for their assistance in reaching nest sites in historical monuments. We thank Claudia Hoffmann, Harald Mannsberger, Georg Witting and the Environmental Protection Bureau of Vienna for permission to use photographs taken during our study and orthophotos. We would like to thank Birdlife Austria, especially Norbert Teufelbauer and all the volunteering ornithologists working on the breeding bird survey. We wish to thank Benjamin Seaman, Julien Terraube and three anonymous reviewers for thoughtful and constructive comments on the manuscript.

\section{Author details}

${ }^{1}$ Department of Integrative Zoology, University of Vienna, Althanstraße 14, Vienna A-1090, Austria. ${ }^{2} 1$ st Zoological Department, Museum of Natural History Vienna, Burgring 7, Vienna A-1010, Austria. ${ }^{3}$ Max Planck Institute for Ornithology, Communication and Social Behaviour Group, Eberhard Gwinner-Straße, Seewiesen D-82319, Germany. ${ }^{4}$ BirdLife Austria, Museumsplatz 1/10/8, Vienna A-1070, Austria. ${ }^{5}$ University of Veterinary Medicine, Veterinärplatz 1, Vienna A-1210, Austria.

\section{Received: 18 December 2013 Accepted: 17 April 2014}

Published: 27 May 2014

\section{References}

1. Ramalho CE, Hobbs RJ: Time for a change: dynamic urban ecology. Trends Ecol Evol 2012, 27:179-188.

2. Marzluff JM: Worldwide urbanization and its effects on birds. In Avian ecology and conservation in an urbanizing world. Edited by Marzluff JM, Bowman R, Donnelly R. Boston: Kluwer Academic Publishers; 2001, 19-48.

3. Lososová Z, Chytrý M, Tichý L, Danihelka J, Fajmon K, Hájek O, Kintrová K, Láníková D, Otýpková Z, Ǩehořek V: Biotic homogenization of Central European urban floras depends on residence time of alien species and habitat types. Biol Conserv 2012, 145:179-184.

4. McKinney ML: Urbanization as a major cause of biotic homogenization. Biol Conserv 2006, 127:247-260

5. Rensburg BJ, Peacock DS, Robertson MP: Biotic homogenization and alien bird species along an urban gradient in South Africa. Landsc Urban Plann 2009, 92:233-241.

6. Miller JR, Hobbs RJ: Conservation where people live and work. Conserv Biol 2002, 16:330-337.

7. McDonald RI, Kareiva P, Forman RTT: The implications of current and future urbanization for global protected areas and biodiversity conservation. Biol Conserv 2008, 141:1695-1703.

8. Slabbekoorn H, Ripmeester EAP: Birdsong and anthropogenic noise: implications and applications for conservation. Mol Ecol 2008, 17:72-83.

9. Zhou D, Chu L: How would size, age, human disturbance, and vegetation structure affect bird communities of urban parks in different seasons? Journal Ornithology 2012, 153:1101-1112.

10. Nemeth $\mathrm{E}$, Brumm H: Blackbirds sing higher-pitched songs in cities: adaptation to habitat acoustics or side-effect of urbanization? Anim Behav 2009, 78:637-641.

11. Dominoni D, Goymann W, Helm B, Partecke J: Urban-like night illumination reduces melatonin release in European blackbirds (Turdus merula): implications of city life for biological time-keeping of songbirds. Frontiers In Zoology 2013, 10:60

12. Chamberlain DE, Cannon AR, Toms MP, Leech DI, Hatchwell BJ, Gaston KJ: Avian productivity in urban landscapes: a review and meta-analysis. Ibis 2009, 151:1-18.

13. Shanahan DF, Strohbach MW, Warren PS, Fuller RA: The challenges of urban living. In Avian Urban Ecology Behavioural and Physiological Adaptations. Edited by Gil D, Brumm H. Oxford University Press: Oxford, UK 2014, 3-20.
14. Møller AP, Diaz M, Flensted-Jensen E, Grim T, Ibáñez-Álamo J, Jokimäki J, Mänd R, Markó G, Tryjanowski P: High urban population density of birds reflects their timing of urbanization. Oecologia 2012, 170:867-875.

15. Møller AP: Successful city dwellers: a comparative study of the ecological characteristics of urban birds in the Western Palearctic. Oecologia 2009, 159:849-858.

16. Blair RB: Land use and avian species diversity along an urban gradient. Ecol Appl 1996, 6:506-519.

17. González-Oreja JA: Birds of different biogeographic origins respond in contrasting ways to urbanization. Biol Conserv 2011, 144:234-242.

18. Chace JF, Walsh JJ: Urban effects on native avifauna: a review. Landsc Urban Plann 2006, 74:46-69.

19. Schlaepfer MA, Runge MC, Sherman PW: Ecological and evolutionary traps. Trends Ecol Evolution 2002, 17:474-480.

20. Cramp S, Tomlins AD: The birds of inner London 1951-65. Br Birds 1966, 59:209-233.

21. Kostrzewa R, Kostrzewa A: Der turmfalke. überlebensstrategien eines greifvogels: (The Kestrel. Survival strategies of a raptor species). Aula Verlag: Wiesbaden; 1993.

22. Darolová A: Nesting of Falco tinnunculus (Linnaeus, 1758) in the urban agglomeration of Bratislava. Biologia (Bratisl) 1992, 47:389-397.

23. Piattella A, Salvati L, Manganaro A, Fattorini S: Spatial and temporal variations in the diet of the common Kestrel (Falco tinnunculus) in Rome, Italy. J Raptor Res 1999, 33:172-175.

24. Rejt L: Peregrine Falcon and Kestrel in urban environment the case of Warsaw. In Naturschutz und Verhalten. Volume 2/2001. Edited by Gottschalk E, Barkow A, Mühlenberg M, Settele J. UFZ-Bericht; 2001, 81-85.

25. Romanowski J: On the diet of urban Kestrels (Falco tinnunculus) in warsaw. Buteo 1996, 8:123-130

26. Salvati L, Manganaro A, Fattorini S, Piattella E: Population features of kestrels Falco tinnunculus in urban, suburban and rural areas in central Italy. Acta Ornitholigica 1999, 34:53-58.

27. Sommani E: Note sulla biologia di alcune coppie di Gheppio, Falco tinnunculus, presenti in Roma. Riv Ital Orn Milano 1986, 56:40-52.

28. Garaffa PI, Filloy J, Bellocq MI: Bird community responses along urbanrural gradients: Does the size of the urbanized area matter? Landsc Urban Plann 2009, 90:33-41.

29. Sorace A, Gustin M: Distribution of generalist and specialist predators along urban gradients. Landsc Urban Plann 2009, 90:111-118.

30. Lerman SB, Warren PS, Gan H, Shochat E: Linking foraging decisions to residential yard bird composition. PLoS One 2012, 7:e43497.

31. Pellissier V, Cohen M, Boulay A, Clergeau P: Birds are also sensitive to landscape composition and configuration within the city centre. Landsc Urban Plann 2012, 104:181-188.

32. Wichmann G, Dvorak M, Teufelbauer N, Berg H-M: Die Vogelwelt Wiens Atlas der Brutvögel. (The Avifauna of Vienna - Atlas of Breeding Birds). Verlag Naturhistorisches Museum Wien: Wien; 2009

33. Sumasgutner P, Krenn HW, Düesberg J, Gaspar T, Gamauf A: Diet specialisation and breeding success along an urban gradient: the kestrel (Falco tinnunculus) in Vienna, Austria. Beiträge Zur Jagd Und Wildforschung 2013, 38:385-397.

34. Kübler S, Kupko S, Zeller U: The kestrel (Falco tinnunculus) in Berlin: investigation of breeding biology and feeding ecology. Journal Ornithology 2005, 146:271-278.

35. Riegert J, Fuchs R: Fidelity to roost sites and diet composition of wintering male urban common kestrels falco tinnunculus. Acta Ornithologica 2011, 46:183-189.

36. Strasser EH, Heath JA: Reproductive failure of a human-tolerant species, the American kestrel, is associated with stress and human disturbance. $J$ Appl Ecol 2013, 50:912-919.

37. Crawley MJ: Chapter 16. Proportion Data. In The R Book. Edited by Crawley MJ. London: John Wiley \& Sons; 2007, 569-591.

38. Jenrich J, Löhr P-W, Müller F: Kleinsäuger: Körper-und Schädelmerkmale. Imhof: Ökologie; 2010.

39. Spitzenberger F: Die Säugetierfauna Österreichs. Austria Medien-Service: Graz; 2001.

40. Mitter G, Sumasgutner P, Gamauf A: City centre or periphery? Distribution and morphological adaptation of Apodemus taxa along an urban gradient. Beiträge Zur Jagd Und Wildforschung 2013, 38:305-319.

41. Newton I: Population ecology of raptors. Vermillion. SD U.S.A: Buteo Books; 1979, $55-75$

42. Village A: The role of nest-site availability and territorial behaviour in limiting the breeding density of Kestrels. J Anim Ecol 1983, 52:635-645. 
43. Kokko H, Sutherland WJ: Ecological traps in changing environments: Ecological and evolutionary consequences of a behaviourally mediated Allee effect. Evol Ecol Res 2001, 3:537-551

44. Hromada M, Antczak M, Valone TJ, Tryjanowski P: Settling decisions and heterospecific social information use in shrikes. PLoS One 2008, 3:e3930.

45. Stamps JA: The silver spoon effect and habitat selection by natal dispersers. Ecol Lett 2006, 9:1179-1185.

46. Robertson BA, Hutto RL: A framework for understanding ecological traps and an evaluation of existing evidence. Ecology 2006, 87:1075-1085.

47. Battin J: When good animals love bad habitats: Ecological traps and the conservation of animal populations. Conserv Biol 2004, 18:1482-1491.

48. Gamauf A, Tebb G, Nemeth E: Honey buzzard Pernis apivorus nest site selection in relation to habitat and the distribution of Goshawk Accipiter gentilis. Ibis 2013, 155:258-270.

49. Fuller RJ: Birds and habitat: relationships in changing landscapes. New York: Cambridge University Press; 2012.

50. Chalfoun AD, Schmidt KA: Adaptive breeding-habitat selection: Is it for the birds? Auk 2012, 129:589-599.

51. Sergio F, Blas J, Forero MG, Donzar JA, Hiraldo F: Sequential settlement and site dependence in a migratory raptor. Behav Ecol 2007, 18:811-821.

52. Fretwell SD: Populations in a seasonal environment. Princeton, N.J.: Princeton University Press; 1972.

53. Charter M, Izhaki I, Bouskila A, Leshem Y, Penteriani V: The effect of different nest types on the breeding success of eurasian kestrels (falco tinnunculus) in a rural ecosystem. J Raptor Res 2007, 41:143-149.

54. López BC, Potrony D, López A, Badosa E, Bonada A, Saló R: Nest-box use by boreal owls (aegolius funereus) in the pyrenees mountains in spain. J Raptor Res 2010, 44:40-49.

55. Tella JL, Hiraldo F, Donazar-Sancho JA, Negro JJ: Costs and Benefits of Urban nesting in the lesser Kestrel. In Raptors in Human Landscapes, Adaptations to Built and Cultivated Environments. Edited by Bird DM, Varlan DE, Negro JJ. New York: Academic Press; 1996:53-60.

56. Stracey CM: Resolving the urban nest predator paradox: The role of alternative foods for nest predators. Biol Conserv 2011, 144:1545-1552.

57. Evans KL, Newson SE, Gaston KJ: Habitat influences on urban avian assemblages. Ibis 2009, 151:19-39.

58. Village A: The Kestrel. London: T \& AD Poyser; 1990.

59. Clutton-Brock TH: Sex ratio variation in birds. Ibis 1986, 128:317-329.

60. Anderson DJ, Reeve J, Bird DM: Sexually dimorphic eggs, nestling growth and sibling competition in American Kestrels Falco sparverius. Funct Ecol 1997, 11:331-335.

61. Ingraldi MF: A skewed sex ratio in Northern Goshawks: is it a sign of a stressed population? J Raptor Res 2005, 39:247.

62. Wu H, Wang $H$, Jiang $Y$, Lei $F$, Gao W: Offspring sex ratio in Eurasian Kestrel (Falco tinnunculus) with reversed sexual size dimorphism. Chinese Birds 2010, 1:36-44.

63. Rutz C: Brood sex ratio varies with diet composition in a generalist raptor. Biol J Linn Soc 2012, 105:937-951.

64. Millon A, Bretagnolle V: Nonlinear and population-specific offspring sex ratios in relation to high variation in prey abundance. Oikos 2005, 108:535-543.

65. Dijkstra C, Daan S, Buker JB: Adaptive seasonal variation in the sex ratio of kestrel broods. Funct Ecol 1990, 4:143-147.

66. Rejt L, Gryczynska-Siemiatkowska A, Rutkowski R, Malewska A: Does egg sex ratio in Urban Kestrels (Falco tinnunculus) differ from parity? Pol J Ecol 2005, 53:545-552.

67. Arroyo B: Sex-biased nestling mortality in the Montagu's harrier Circus pygargus. J Avian Biol 2002, 33:455-460

68. Goodwin TW: The Biochemistry of the Carotenoids. 2nd edition. London, New York: Chapman and Hall; 1980.

69. Kirkwood JK: Energy requirements for maintenance and growth of wild mammals, birds and reptiles in captivity. J Nutr 1991, 121:S29-34.

70. Negro JJ, Bustamante J, Melguizo C, Ruiz JL, Grande JM: Nocturnal activity of lesser kestrels under artifical lighting conditions in Seville, Spain. J Raptor Res 2000, 34:327-329.

71. Riegert J, Fainová D, Mikeš V, Fuchs R: How urban Kestrels Falco tinnunculus divide their hunting grounds: partitioning or cohabitation? Acta Ornithologica 2007, 42:69-76.

72. Riegert J, Dufek A, Fainová D, Mikeš V, Fuchs R: Increased hunting effort buffers against vole scarcity in an urban Kestrel Falco tinnunculus population: capsule In years with low vole abundance birds visited hunting grounds more frequently and for longer. Bird Study 2007, 54:353-361.

73. Korpimäki E: Diet of the Kestrel Falco tinnunculus in the breeding season. Ornis Fenn 1985, 62:130-137.

74. Quere J: Approche du régime alimentaire du Faucon crécerelle (Falco tinnunculus L., 1758) en milieu urbain (Paris intra muros) et durant la période de reproduction. (Study of the kestrel's (Falco tinnunculus) diet in a urban environment (Paris) during the breeding period). Le Passer 1990, 27:92-107.

75. Costantini D, Casagrande S, Di Lieto G, Fanfani A, Dell'Omo G: Consistent differences in feeding habits between neighbouring breeding kestrels. Behaviour 2005, 142:1409-1421.

76. Terraube J, Arroyo B, Madders M, Mougeot F: Diet specialisation and foraging efficiency under fluctuating vole abundance: a comparison between generalist and specialist avian predators. Oikos 2011, 120:234-244.

77. Kark S, Iwaniuk A, Schalimtzek A, Banker E: Living in the city: can anyone become an 'urban exploiter'? J Biogeogr 2007, 34:638-651.

78. Hollander FA, Titeux N, Van Dyck H: Habitat-dependent prey availability and offspring provisioning explain an ecological trap in a migratory bird. Funct Ecol 2013, 27:702-709.

79. Török J, Hegyi G, Tóth L, Könczey R: Unpredictable food supply modifies costs of reproduction and hampers individual optimization. Oecologia 2004, 141:432-443.

80. Kloskowski J: Fish stocking creates an ecological trap for an avian predator via effects on prey availability. Oikos 2012, 121:1567-1576.

81. Kristan WB: The role of habitat selection behavior in population dynamics: source-sink systems and ecological traps. Oikos 2003, 103:457-468.

82. Kupko S, Schlottke L, Rinder J: Der turmfalke (Falco tinnunculus L.) im berliner stadtgebiet - eine auswertung unter besonderer berücksichtigung der monitoringfläche Nr. 376 (Berlin-West). Populationsökologie Greifvogel- und Eulenarten 2000, 4:359-372.

83. Malher F, Lesaffre G, Zucca M, Coatmeur J: Oiseaux nicheurs de Paris. Un atlas urbain. (The breeding birds of Paris. An urban atlas). Paris: Corif. Delachaux et Niestlé; 2010.

84. Gamauf A: Greifvögel in Österreich. Bestand - Bedrohung - Gesetz. (Birds of Prey in Austria. Population - Threat - Law). Umweltbundesamt Wien: Wien; 1991.

85. Zuckerberg B, Bonter DN, Hochachka WM, Koenig WD, DeGaetano AT, Dickinson $\mathrm{J}$ : Climatic constraints on wintering bird distributions are modified by urbanization and weather. J Anim Ecol 2011, 80:403-413.

86. Rotella JJ, Dinsmore SJ, Shaffer TL: Modeling nest-survival data: a comparison of recently developed methods that can be implemented in MARK and SAS. Anim Biodivers Conserv 2007, 27:187-205.

87. Eck S, Fiebig J, Fiedler W, Heynen I, Nicolai B, Töpfer T, van den Elzen R, Winkler R, Woog F: DO-G Deutsche Ornithologen-Gesellschaft: measuring birds vögel vermessen. Christ Media Natur 2011.

88. Griffiths R, Double MC, Orr K, Dawson RJG: A DNA test to sex most birds. Mol Ecol 1998, 7:1071-1075.

89. Wellbrock A, Bauch C, Rozman J, Witte K: Buccal swabs as a reliable source of DNA for sexing young and adult common swifts (Apus apus). Journal Ornithology 2012, 153:991-994.

90. Fridolfsson A-K, Ellegren $\mathrm{H}$ : A simple and universal method for molecular sexing of non-ratite birds. J Avian Biol 1999, 30:116-121.

91. Nesje M, Røed KH: Sex identification in falcons using microsatellite DNA markers. Hereditas 2000, 132:261-263

92. Arroyo BE: Diet of Montagu's Harrier Circus pygargus in central Spain: analysis of temporal and geographic variation. Ibis 1997, 139:664-672.

93. von Blotzheim UN G, Bauer KM: Handbuch der Vögel Mitteleuropas. Columbiformes - Piciformes. (Handbook of the Birds of Central Europe, Columbiformes - Piciformes). Wiesbaden: Aula-Verlag; 1980, 232-234.

94. Levins R: Evolution in changing environments; some theoretical explorations. Princeton, N.J.: Princeton University Press; 1968.

95. Südbeck P, Andretzke H, Fischer S, Gedeon K, Schikore T, Schröder K Sudfeldt C: Methodenstandards zur Erfassung der Brutvögel Deutschlands. (Methods for the detection of breeding birds in Germany). Die Deutsche Bibliothek: Radolfszell; 2005

96. Krebs CJ: Population cycles revisited. J Mammal 1996, 77:8-24.

97. Janova E, Nesvadbrova J, Heroldova M, Bryja J: Effectiveness of two trapping protocols for studying the demography of common voles. Hystrix Italian Journal of Mammalogy 2010, 21:189-193. 
98. Wiener Stadtgebiet MG:Ki: Der Einfluss öffentlicher Parks und Grünanlagen auf Häufigkeit und Morphologie. (Rodents in the city of Vienna: Distribution and morphological adaptation along an urban gradient). Master thesis. Fakultät für Lebenswissenschaften: Universität Wien; 2012, 19-27.

99. Bates D, Maechler M: Ime4: Linear mixed-effects models using S4 classes. R package version 0.999375-32; 2013.

100. Zuur AF, leno EE, Walker NJ, Saveliev AA, Smith GM: Mixed effects models and extensions in ecology with R. New York, NY: Springer; 2009, 220-223.

101. Burnham KP, Anderson DR, Huyvaert KP: AIC model selection and multimodel inference in behavioral ecology: some background, observations, and comparisons. Behav Ecol Sociobiol 2011, 65:23-35.

102. Tremblay A, Ransijn J: Package 'LMERConvenienceFunctions'; 2013.

103. Nakagawa S, Schielzeth $\mathrm{H}$ : A general and simple method for obtaining $R^{2}$ from generalized linear mixed-effects models. Methods Ecol Evolution 2013, 4:133-142.

104. Barton K: MuMIn: Multi-model inference. R package version 1.9.5; 2013

105. White GC, Burnham KP: Program MARK: survival estimation from populations of marked animals. Bird Study 1999, 46:S120-S139.

106. Laake JL, Johnson DS, Conn PB: Marked: an R package for maximumlikelihood and MCMC analysis of capture-recapture data. Methods Ecol Evolution 2013, 4:885-890.

107. Krebs CJ: Ecological Methodology. 4th edition. Menlo Park, California: Benjamin / Cummings; 2014, 149-159.

108. ASAB: Guidelines for the treatment of animals in behavioural research and teaching. Anim Behav 2012, 83:301-309.

doi:10.1186/1742-9994-11-48

Cite this article as: Sumasgutner et al: Hard times in the city - attractive nest sites but insufficient food supply lead to low reproduction rates in a bird of prey. Frontiers in Zoology 2014 11:48.

\section{Submit your next manuscript to BioMed Central and take full advantage of:}

- Convenient online submission

- Thorough peer review

- No space constraints or color figure charges

- Immediate publication on acceptance

- Inclusion in PubMed, CAS, Scopus and Google Scholar

- Research which is freely available for redistribution 